\title{
Correction to: Spatial interactive projections in robot-based inspection systems
}

\author{
Philipp Bauer $^{1} \cdot$ Fridolin Fink $^{1} \cdot$ Alejandro Magaña ${ }^{1} \cdot$ Gunther Reinhart ${ }^{1}$ \\ Published online: 9 June 2021 \\ (C) Springer-Verlag London Ltd., part of Springer Nature 2021
}

\section{Correction to: The International Journal of Advanced Manufacturing Technology (2020) 107:2889-2900 https://doi.org/10.1007/s00170-020-05220-1}

The article Spatial interactive projections in robot-based inspection systems, written by Philipp Bauer, Fridolin Fink, Alejandro Magaña and Gunther Reinhart, was originally published Online First without Open Access. After publication in volume 107, issue 5-6, page 2889-2900 the author decided to opt for Open Choice and to make the article an Open Access publication. Therefore, the copyright of the article has been changed to $\odot$ The Author(s) 2021 and the article is forthwith distributed under the terms of the Creative Commons Attribution 4.0 International License, which permits use, sharing, adaptation, distribution and reproduction in any medium or format, as long as you give appropriate credit to the original author(s) and the source, provide a link to the Creative Commons license, and indicate if changes were made. The images or other third party material in this article are included in the article's Creative Commons license, unless indicated otherwise in a credit line to the material. If material is not included in the article's Creative Commons license and your intended use is not permitted by statutory regulation or exceeds the permitted use, you will need to obtain permission directly from the copyright holder. To view a copy of this license, visit http://creativecommons.org/licenses/by/4.0.

Publisher's note Springer Nature remains neutral with regard to jurisdictional claims in published maps and institutional affiliations.

The online version of the original article can be found at https://doi.org/ 10.1007/s00170-020-05220-1

Philipp Bauer

philipp.bauer@iwb.mw.tum.de

Fridolin Fink

fridolin.fink@tum.de

Alejandro Magaña

alejandro.magana@iwb.mw.tum.de

Gunther Reinhart

gunther.reinhart@iwb.mw.tum.de

1 Institute for Machine Tools and Industrial Management, Technical University of Munich, Boltzmannstr. 15, 85748 Garching, Germany 